\title{
PENEGAKAN HUKUM TERHADAP TINDAK PIDANA DI INDONESIA MELAUI HUKUM PIDANA POSITIF DAN HUKUM PIDANA ISLAM
}

\author{
Safaruddin Harefa \\ Fakultas Hukum Universitas Mohammad Natsir Bukittinggi \\ E-Mail: safaruddinharefa1993@gmail.com
}

\begin{abstract}
Criminal law in Indonesia is currently felt to be not fulfilling a justice and peace in social life, because the number of crimes that have occurred lately makes the law no longer a social control but rather the number of certain people who use the law as a mouthpiece for doing evil, this is due to the lack of deterrent effects caused by the criminal law itself. This paper is an analysis of how criminal law is able to achieve the intended legal objectives which are analyzed from the study of criminal law enforcement that currently applies and law enforcement through Islamic criminal law. The results of this analysis state that currently in Indonesia still using criminal law (positive law) originating (spirit and soul) brought by invaders, namely Dutch Law, until now there has not been a complete renewal of criminal law but only a renewal Partial. Furthermore, the results of the analysis also explain that the application of Islamic criminal law needs to be considered, because in Islamic criminal law according to the author's analysis that Islamic law will be able to provide a deterrent effect on an act that has been committed by a criminal offender, therefore the need for legal reform criminal by adopting several spirits from Islamic criminal law.
\end{abstract}

Keywords: Law Enforcement, Criminal, Islamic, Legal Reform

\begin{abstract}
ABSTRAK
Hukum pidana di Indonesia saat ini dirasakan kurang memenuhi suatu keadilan serta ketentraman dalam kehidupan bermasyarakat, sebab banyaknya suatu tindak pidana yang terjadi akhir-akhir ini menjadikan hukum itu tidak lagi sebagai kontrol sosial melainkan banyaknya orang-orang tertentu memanfaatkan hukum sebagai corong untuk berbuat kejahatan, ini disebabkan kurangnya efek jera yang ditimbulkan oleh hukum pidana itu sendiri. Tulisan ini merupakan analisa bagaimana hukum pidana itu mampu mencapai tujuan hukum yang dicita-citakan yang di analisa dari kajian penegakan hukum pidana yang saat ini berlaku dan penegakan hukum melalui hukum pidana islam. Hasil dari analisa ini menyatakan bahwa saat ini di Indonesia masih menggunakan hukum pidana (hukum positif) yang bersumber (ruh dan jiwa) yang dibawa oleh penjajah yaitu Hukum Negara Belanda, sampai saat ini belum adanya suatu pembaharuan hukum pidana yang secara Menyeluruh melainkan hanya pembaharuan secara parsial. Selanjutnya hasil dari analisa juga menerangkan bahwa pemberlakuan hukum pidana islam perlu di pertimbangkan, sebab dalam hukum pidana islam menurut analisa penulis bahwa hukum islam akan mampu memberikan suatu efek jera terhadap suatu perbuatan yang telah dilakukan oleh pelaku tindak pidana, maka dari itu perlu adanya pembaharuan hukum pidana dengan mengadopsi beberapa ruh dari hukum pidana islam.
\end{abstract}

Kata Kunci : Penegakan Hukum, Pidana, Islam, Pembaharuan hukum 


\section{Pendahuluan}

Akhir masa pemerintahan Orde Baru memunculkan harapan bahwa Indonesia akan berkembang menjadi negara hukum demokratis yang menghormati dan menjunjung tinggi rule of law. Dalam rangka mewujudkan hal tersebut telah diambil pelbagai langkah formal, antara lain, menambahkan Bab XA ke dalam konstitusi (UUD 1945) dan menandatangani instrumen hak asasi manusia internasional seperti Kovenan Internasional tentang Hak-hak Sipil dan Politik (ICCPR). Dengan itu semua Indonesia baik secara eksternal maupun internal mengikatkan diri untuk bertindak sejalan dengan (tuntutan) rule of law. Kewajiban serupa juga muncul berkenaan dengan (pengembangan dan penegakan) hukum pidana di Indonesia. Kewajiban yang disebut terakhir mencakup dua hal: pertama kewajiban untuk mengennmbangkan hukum pidana yang fungsional, dan kedua, kewajiban untuk memberikan jaminan (dan perlindungan) hak (dasar) kepada setiap orang, tanpa kecuali dan tanpa memandang perbedaan-perbedaan di antara mereka. Untuk mengukur dan menguji apakah negara memenuhi syarat-syarat yang dituntut rule of law dipergunakan tolok ukur prosedural, materiil dan institusional (Bedner, 2010). Di dalam tulisan ini akan dilakukan pengujian berdasarkan tolok ukur materiil (atau asasasas(hukum) fundamental). ${ }^{1}$

Dalam Pasal 1 ayat (3) Undang-undang Dasar 1945 telah ditegaskan bahwa Indonesia adalah negara Hukum. Dalam kehidupan bernegara, salah satu yang harus ditegakkan adalah suatu kehidupan hukum di dalam kehidupan bermasyarakat. Pandangan ini diyakini tidak hanya disebabkan dianutnya paham negara hukum, melainkan lebih melihat secara kritis kecenderungan yang terjadi di dalam kehidupan bangsa Indonesia yang berkembang kearah masyarakat modern. $^{2}$

Hukum ada pada setiap masyarakat diama pun di muka bumi ini. Primitif dan modernnya suatu masyarakat pasti memiliki hukum. Oleh karena itu, keberadaan (eksistensi) hukum sifatnya universal. Hukum tidak bisa dipisahkan dengan masyarakat, keduanya mempunyai hubungan timbal balik. ${ }^{3}$

Membicarakan hukum pidana seringkali membuat orang membayangkan yang bersifat jahat, kotor, dan penuh tipu daya. Pokoknya ketika orang berbicara tentang hukum pidana, maka yang terbayang adalah penumpasan kejahatan oleh polisi, jaksa, dan hakim. Yang juga terbayang adalah

\footnotetext{
${ }^{1}$ Agustinus Pohan, Topo Santoso, dan Martin Moerings, 2012, Hukum pidana dalam perspektif, Denpasar: Pustaka Larasan, Jurnal Hukum yang di Terjemahkan, hlm 3

2 Teguh Prasetiyo \& abdul Halim Barkatullah, 2005, Politik Hukum Pidana, Yogyakarta: Pustaka Pelajar, hlm, 6 .

${ }^{3}$ Ibid.
} 
para pelaku kejahatan atau penjahat yang umumnya berasal dari kalangan ekonomi lemah, brutal, dan marginal. Karena itu pada umumnya bersumber dari masalah kemiskinan. ${ }^{4}$

Pada dasarnya hukum pidana memang berfokus pada pengaturan tentang masalah kejahatan yang terjadi di tengah masyarakat. Hukum pidana menjadi penjaga agar masyarakat terhindar dari kejahatan. Hukum pidana menjadi penjaga agar masyarakat terhindar dari kejahatan. Kalau Makamah Konstitusi sering disebut sebagai The Guardian of Constution, maka hukum pidana dalam hubungannya dengan kejahatan layak disebut sebagai The Guardian of Security yang berusaha menberikan jaminan agar masyarakat tidak menjadi korban kejahatan. ${ }^{5}$

Kalau kita bisa flesback ke belakang melihat kasus-kasus yang terjadi banyak yang mendapatkan kritikan dari masyarakat terhadap penerapan hukum positif saat ini hanya sebagai macan dalam kertas bahkan tidak memiliki taring yang kuat menjerat para pelaku kejahatan. Kita melihat di dalam peraturan perundang-undangan kita setiap kejahatan yang dikenai sanksi pidana (nestapa) menurut Pasal 10 KUHP ancaman pidana dibagi kedalam 2 bagian yaitu Pidana Pokok yang berisikan Pidana Mati, Pidana Penjara, Pidana Kurungan dan Pidana Denda,

${ }^{4}$ Erdianto Efendi, 2011, Hukum Pidana Indonesia Suatu Pengantar, Bandung: Refika Aditama, hlm 1 ${ }^{5}$ Ibid. serta Pidana Tambahan berupa Pencabutan beberapa hak, Perampasan barang-barang tertentu, Pengumuman putusan hakim.

Saat ini, di negara indonesia marak terjadi aksi kejahatan yang amat meresahkan dan menakutkan masyarakat. seperti pembegalan dijalan-jalan, pencurian, pencopetan, pembunuhan yang didahului pemerkosaan, serta kejahatan seksualpun merebak dengan pesat, pornografi makin tak terkendali, pelecehan seksual terjadi dimanamana. penyalahgunaan narkotika dan obatobatan terlarang semakin bertambah, dan tindak pidana korupsi yang kian tak terbendung.

Kendala yang sampai saat ini dirasakan oleh negara kita adalah untuk membuat jera atas kejahatan yang telah ada dengan aturan yang telah dibuat oleh penguasa (pemerintah). Kalau kita menimbang sampai saat ini efek jera itu belum terasa sekali terhadap perkembangan sanksi yang diterapkan kepada sipelaku kejahatan. Contoh aturan yang sampai saat ini yang masih kontroversial dan memerlukan perubahan cepat untuk menanggulanginya yaitu pada Pasal 285 KUHP : Barang siapa dengan kekerasan atau ancaman kekerasan memaksa seorang wanita bersetubuh dengan dia di luar perkawinan, diancam karena melakukan perkosaan dengan pidana penjara paling lama 12 (dua belas) tahun.

Berdasarkan uraian latar belakang tersebut di atas, maka penelitian ini ingin 
memahami lebih mendalam mengenai Penegakan Hukum Pidana di Indonesia dalam tindak Pidana Umum Yang Terdapat di Dalam KUHP dan Penerapan Hukum Islam dalam tindak Pidana Yang Terdapat di Dalam KUHP atas dasar hal tersebut, penulis tertarik untuk mengadakan penelitian yang dituangkan dalam bentuk makalah dengan judul "Penegakan Hukum terhadap Tindak Pidana di Indonesia Melaui Hukum Pidana Positif dan Hukum Pidana Islam.”

\section{Metode Penelitian}

Jenis penelitian hukum yang digunakan dalam penelitian ini adalah penelitian hukum normatif. Penelitian hukum normatif merupakan penelitian yang dilakukan atau berfokus pada norma hukum positif berupa data sekunder, yang terdiri atas Kitab Undang-Undang Hukum Pidana (KUHP). Undang-Undang Nomor 8 Tahun 1981 tentang Hukum Acara Pidana yang selanjutnya disebut Kitab Undang-Undang Hukum Acara Pidana (KUHAP) serta Bahan hukum sekunder yang digunakan ialah terdiri atas buku, hasil penelitian, internet, fakta hukum, dan statistik dari data instansi resmi. Pendapat hukum juga diperoleh melalui buku-buku yang ditulis oleh para pakar hukum pidana. Sedangkan Bahan hukum primer yang digunakan ialah berupa peraturan perundang-undangan yang akan dianalisis sesuai dengan 5 tugas ilmu hukum normatif yaitu :
a. Deskripsi hukum positif;
b. Sistematisasi hukum positif;
c. Analisis hukum positif;
d. Interpretasi hukum positif;
e. Menilai hukum positif.

\section{Pembahasan dan Analisa}

\section{Penegakan Hukum Pidana di Indonesia dalam tindak Pidana Umum Yang Terdapat di Dalam KUHP}

Secara umum penegakan hukum dapat diartikan sebagai tindakan menerapkan perangkat sarana hukum tertentu untuk memaksakan sanksi hukum guna menjamin penataan terhadap ketentuan yang ditetapkan tersebut, sedangkan menurut Satjipto Raharjo, penegakan hukum adalah suatu proses untuk mewujudkan keinginan-keinginan hukum (yaitu pikiran-pikiran badan pembuat Undang-Undang yang dirumuskan dalam peraturan hukum) menjadi kenyataan. ${ }^{6}$

Soerjono Soekanto mengemukakan pendapatnya, bahwa kejahatan (tindak pidana) adalah gejala sosial yang senantiasa dihadapi untuk setiap masyarakat di dunia. Apapun usaha untuk menghapuskannya tidak tuntas karena kejahatan itu memang tidak dapat dihapus. Hal itu terutama disebabkan karena tidak semua kebutuhan dasar manusia dapat

\footnotetext{
${ }^{6}$ Satjipto Raharjo, 1983, Masalah Penegakan Hukum, Bandung: Sinar baru, hlm 24
} 
dipenuhi secara sempurna, lagi pula manusia mempunyai kepentingan yang berbeda-beda yang bahkan dapat berwujud sebagai pertentangan yang prinsipil. $^{7}$ Maka untuk menanggulangi suatu kejahatan yang ada maka di perlukan suatu perumusan suatu kebijakan hukum pidana dalam bentuk hukum tertulis.

Adapun tujuan pidana adalah:

1. Reformation berarti memperbaiki atau penjahat menjadi orang baik dan berguna bagi masyarakat.

2. Restraint maksudnya adalah mengasingkan pelanggar dari masyarakat.

3. Retribution ialah pembalasan terhadap pelanggar karena telah melakukan kejahatan.

4. Deterrence, berarti terdakwa sebagai individual maupun orang lain yang potensial menjadi penjahat akan jera atau takut untuk melakukan kejahatan, melihat pidana yang dijatuhkan kepada terdakwa. ${ }^{8}$

Berdasarkan ciri hukum publik, maka dapat dicirikan hukum pidana adalah hukum publik, yaitu:

${ }^{7}$ Soerjono Soekanto, 1999, Pokok Pokok Sosiologi Hukum, cet 9, Jakarta: Raja Grafindo Persada, hlm. 14.

${ }^{8}$ Andi Hamzah, 1994, Azas Azas Hukum Pidana, cet 2, Jakarta: J Rineka Cipta, hlm. 28-29.
1. mengatur hubungan antara kepentingan negara atau masyarakat dengan orang perorangan;

2. kedudukan penguasa negara adalah lebih tinggi daripada orang perorangan. Dengan perkataan lain, orang perorangan disubordinasikan kepada penguasa;

3. penuntutan seseorang (yang melakukan suatu tindakan yang terlarang) tidak tergantung kepada perseorangan (yang dirugikan), melaikan pada umumnya, negara/penguasa wajib menuntut sesorang tersebut;

4. hak subjektif penguasa ditimbulkan oleh peraturan-peraturan hukum pidana subjektif atau hukum pidana positif. 9

Hukum adalah hasil tarik-menarik pelbagai kekuatan politik yang mengejawantah dalam produk hukum. Satjipto Raharjo menyatakan bahwa hukum adalah instrumentasi dari putusan atau keinginan politik sehingga pembuatan peraturan perundang-undangan sarat dengan kepentingan-kepentingan tertentu. Dengan demikian, medan pembuatan UU menjadi medan perbenturan dan kepentingan kepentingan. Badan pembuat UU akan mencerminkan

${ }^{9}$ Erdianto Efendi, 2011, Hukum Pidana Indonesi Suatu Pengantar, Pekanbaru-Bandung: Refika Aditama, hlm 47. 
konfigurasi kekuatan dan kepentingan yang ada dalam masyarakat. ${ }^{10}$

KUHP sendiri terdiri dari 3 buku yaitu buku I, Buku II dan Buku III. Buku I Menagtur tentang Prinsip Pokok dan Aturan Umum, Buku II mengatur tentang Kejahatan, Buku III tentang Pelanggaran. Berdasarkan pembagian ini, maka dalam KUHP tindak pidana dapat dibedakan antara kejahatan dan pelanggaran. Ini sejalan dengan pembedaan delik kee dalam mala in se dan mala prohibita. Kelsen dalam bukunya Teori Murni Tentang Hukum, menyatakan bahwa perbuatan manusia tertentu adalah delik karena tata hukum meletakkan kepada perbuatan ini sebagai kondisi, suatu sanksi sebagai konsekuensinya. Di dalam teori hukum pidana tradisional dibuat perbedaan mala in se dan mala prohibita, yakni perbuatan yang dengan sendirinya dianggap jahat, dana perbuatan yang dianggap jahat hanya karena perbuatan tersebut dilarang oleh suatu tata sosial positif. $^{11}$

Di dalam uraian di atas dapat kita melihat bahwasanya setiap tindak pidana yang umum sudah di atur oleh KUHP Indonesia yang lama mulai dari kejahatan yang ringan sampai dengan kejahatan

\footnotetext{
${ }^{10}$ Satjipto Raharjo, 2002 Sosiologi Hukum, Perkembangan, Metode dan Pilihan Masalah, Surakarta: Muhammadiyah University Press, hlm. 126.

${ }^{11}$ Erdianto Efendi, op.cit, hlm 63
}

yang berat, serta pelanggaran yang ringan sampai dengan pelanggaran yang berat. Semua tindak pidana yang dicantumkan di dalam KUHP itu juga memiliki stelsel pemidanaan/ancaman yang berbeda-beda pula sesuai dengan kejahatan yang dilakukan oleh si pembuat tindak pidana. Pada Pasal 10 KUHP telah mencantumkan Stelsel pemindanaan/ancaman pidana terhadap tindak pidana umum, yaitu Pidana Pokok dan Pidana Tambahan. Pidana Pokok terdiri atas Pidana Mati, Pidana, Pidana Penjara, Pidana Kurungan, Pidana Denda dan Pidana tutupan, sedangkan Pidana Tambahan di kategorikan kedalam; Pencabutan hak-hak tertentu, Perampasan barang-barang tertentu, dan Pengumuman Putusan Hakim.

Secara keilmuan, bentuk pidana dapat dibedakan berdasarkan objek yang dapat dipidana. SR. Sianturi membagi bentuk-bentuk pidana ke dalam beberpa bentuk, yaitu;

1. Pidana jiwa; Pidana mati;

2. Pidana badan pelaku; pencambukan dengan rotan, pemotongan bagian badan (potong jari tangan), dicap bara, dan lain sebagainya;

3. Pidana kemerdekaan pelaku; pidana penjara, pidana tutupan, pidana kurungan, pembuangan, pengasingan, pengusiran, penginterniran, penawanan, dan sebagainya; 
4. Pidana kehormatan pelaku misalnya pencabutan hak tertentu, pencabutan izin mengemudi, pengumuman putusan hakim, teguran dan lain sebaginya;

5. Pidana atas garta benda/kekayaan; pidana denda, perampsan barang tertentu, membayar harga sutau barang yang tidak belum dirampas sesuai taksiran dan lain sebaginya. ${ }^{12}$

Berkaca dari apa yang disampaikan di atas telah tampaklah bagaimana prosedur pemidanan/ancaman pidana yang diberikan oleh negara/melalui KUHP kepada para pelaku tindak pidana. Dari keseluruhan tersebut tulisan ini akan mencoba berfokus kepada ancaman pidana pokok.

\section{a. Pidana Mati}

Pidana Mati merupakan pidana yang paling keras dalam sistem pemidanaan. Sungguhpun demikian, pidana mati paling banyak dimuat dalam hukum pidana di banyak negara dengan cara eksekusi berbagai bentuk mulai dari panjung, digantung, disetrum listrik, sisuntik hingga di tembak. $^{13}$

Pelaksanaan pidana mati dilakukan dengan ditembak sampai mati, caracara pelaksanaan untuk terpidana justiabel peradilan sipil diatur dalam

\footnotetext{
${ }^{12}$ Erdianto Efendi, op.cit, hlm 145

${ }^{13}$ Erdianto Efendi, op.cit, hlm 153
}

Pasal 2 sampai dengan Pasal 16 Undang-Undang No. 2 PNPS Tahun 1964, sedang untuk terpidana Yustiabel peradilan militer diatur dalam Pasal 17. dengan keluarnya Undang-Undang No. 2 PNPS Tahun 1964, ketentuan dalam Pasal 11 KUHP sudah tidak berlaku. ${ }^{14}$

Di dalam Pasal 9 Undang-Undang No. 2 PNPS Tahun 1964 meyatakan bahwa; Pidana mati dilaksanakan tidak di muka umum dan dengan cara sesederhana mungkin, kecuali ditetapkan lain oleh Presiden. Pada konteksnya yang terjadi di negara indonesia pidana mati dilaksanakan di Lapas Nusakambangan yang terletak di sebuah pulau di Jawa Tengah yang lebih dikenal sebagai tempat terletaknya beberapa Lembaga Permasyarakatan (Lapas) berkeamanan tinggi di indonesia.

\section{b. Pidana Penjara}

Pidana Penjara adalah salah satu bentuk dari pidana perampasan kemerdekaan. Ada bebeapa sistem dalam pidana penjara, yaitu;

1. Pensylvania System: terpidana menurut sistem ini dimasukkan dalam sel-sel tersendiri, ia tidak boleh menerima tamu baik dari luar maupun sesama narapidana, ia tidak boleh bekerja diluar sel satu-satunya

\footnotetext{
${ }^{14}$ Teguh Prasetyo, 2010, Hukum Pidana Edisi Revisi, Yogyakarta: Rajawali Pers, hlm. 117.
} 
pekerjaan adalah membaca buku suci yang diberikan padanya. Karena pelaksanannya dilakukan di sel-sel maka disebut Cellulaire System.

2. Auburn System: pada waktu malam ia di masukkan dalam sel secara sendir-sendir, pada waktu siangny diwajibkan bekerja dengan narapidana lainnya, tetapi tidak boleh saling berbicara di antara mereka, biasa disebut dengan Silent System.

\section{Progressive System: cara} pelaksanaan pidana menurut sistem ini adalam bertahap, biaasa disebut dengan English/Ire System. ${ }^{15}$

\section{c. Pidana Kurungan}

Pidana Kurungan ini uuga merupakan salah satu bentuk pidana perampasan kemerdekaan, akan tetapi ini dalam beberpa hal lebih ringan dari pada pidana penjara. Ketentuanketentuan tersebut sebagai berikut:

1. para terpidana kurungan mempunyai hal pistole. Yang artinya mereka mempunya hak atau kesempatan untuk mengurusi makanan dan alat tidur tersendiri atas biaya sendiri/ Pasal 23 KUHP

2. para terpidna mengerjakan pekerjaan yang diwajibkan, akan tetapi lebih ringan dibandingkan terpidana penjara/ Pasal 19 KUHP

3. meskipun ancaman pidana kurungan adalah satu tahun. Maksimum ini boleh sampai 1 tahun 4 bulan dalam hal terjadi pemberatan pidana, karena perbarengan, atau karena ketentuan Pasal 52 atau Pasal 52a (Pasal 18 KUHP)

4. apabila terpidana penjara dan terpidana kurungan menjalani pidana masing-masing di situ tempat permasyarakatan, maka terpidana kurungan harus terpisah tempatnya (Pasal 28 KUHP)

5. pidana kurungan biasanya dilaksanankan di dalam daerahnya terpidananya sendir/biasanya tidak diluar daerah yang bersangkutan. ${ }^{16}$

\section{d. Pidana Denda}

Pidana denda adalah hukuman berupa kewajiban seseorang untuk mengembalikan keseimbangan hukum atau menebus dosanaya dengan pembayaran sejumlah uang tertentu. Minimum pidana denda adalah $\mathrm{Rp}$. 0,25 (dua puluh lima sen) X 15, meskipun tidak ditentukan secara umum melainkan dalam pasal-pasal tindak pidana yang bersangkutan dalam Buku I dan Buku II KUHP. Di luar KUHP biasanya ditentukan adakalanya

\footnotetext{
${ }^{15}$ Ibid hlm 121.
}

${ }^{16}$ Ibid hlm 122. 
dalam 1 atau 2 pasal bagian terakhir dari undang-undang tersebut, untuk norma-norma tindak pidana yang ditentukan dalam pasal mendahuluinya. ${ }^{17}$

\section{e. Pidana Tutupan}

Pidana tutupan dijatuhkan kepada pelaku apabila ia melakukan suatu kejahatan yang diancam dengan pidana penjara, akan tetapi karena terdorong oleh maksud yang patut di hormati. Pelaksaan tutupan sunyi dicirikan;

1. terpidana diperkenankan memakai celana sendiri;

2. makanan terpidana tutupan harus lebih baik dari terpidana penjara, dan terpidana boleh memperbaiki makanan atas biaya sendir;

3. di dalam Rumah Tahanan diperbolehkan mengadakan penghiburan yang sederhana dan pantas;

4. sedapat-dapatnya dalam Rumah Tahanan diadakan perpustakaan bagi terpidana dan para terpidana diperkenankan membawa bukubuku; apabila terpidana meninggal, jenazahnya sedapat-dapatnya diserahkan kepada keluarga. ${ }^{18}$
${ }^{17}$ Ibid hlm 123.

${ }^{18}$ Ibid.
2. Penerapan Hukum Islam dalam tindak Pidana Yang Terdapat di Dalam KUHP

Reformasi di bidang penegakan hukum dan struktur hukum, bahkan juga di bidang perundang-undangan (substansi hukum), berhubungan erat dengan reformasi di bidang "budaya hukum dan pengetahuan/pendidikan hukum". 19

Peningkatan kualitas keilmuan (antara lain lewat program pendidikan hukum lanjut/ "continuing legal education", program spesialis, magister/S2, dam Doktor/S3) seyogianya merata/meyeluruh pada semua SDM, baik di kalangan lembaga/ (staf dosen) maupun din kalangan legislatif dan penegak hukum. Pemerataan atau keseimbangan kualitas keilmuan dari orang-orang yang terlibat dalam proses penegakan hukum dan keadilan ini, tentunya juga akan berpengaruh pada bobot/kualitas proses peradilan dan kualitas keadilan/keputusan hukum yang dijatuhkan. ${ }^{20}$

Patut di catat, bahwa kualitas keadilan tentunya hanya berkaitan dengan kualitas kelimuan dan ilmu pengetahuan lain-lainya, tetapi yang sangat diharapkan masyarakat adalah kualitas "ilmu (pengetahuan) dan sikap tentang

\footnotetext{
${ }^{19}$ Barda Nawawi Arief, 2006, Masalah Openegakan hukum dan Kebijakan hukum Pidana dalam Penanggulangan, Semarang: Kejahatan, Kencana, , hlm. 5.

${ }^{20}$ Ibid. hlm 7
} 
bagaimana menegakkan keadilan", itu sendiri. Para penegak hukum, terutama para hakim, mengetahui pedoman undangundang (dasar hukum dalam menjatuhkan putusan, yaitu Pasal 4 (1) UU. No. 14/1970 jo. UU No. 35/1999 (yang telah diganti menjadi UU No. 4/2004) bahwa peradilan dilakukan "Demi Keadilan Berdasarkan Ketuhanan Yang Maha Esa ". namun tidak sedikit di antyara mereka, termasuk para hakim, yang tidak mengetahui pedoman/tuntutan ilahiah (tuntutan Tuhan Yang Maha Esa) tentang bagaimana menegakkan kebenaran dan keadilan, sebagaimana misalnya terdapat dalam tuntutan Al-Qur'an yang menyatakan antara lain:

1. “Apabila Kamu menghukum dia antara manusia ("bainan naas"), maka hukumlah dengan adil” (QS. An-Nisa : 58)

2. "tegakkanlah kebenaran dan keadilan walau pada dirimu sendiri, ayah ibumu, maupun pada karib kerabat (kronikroni)-mu” (QS. An-Nisa :135)

3. "Wahai orang-orang yang beriman! Jadilah kamu penegak keadilan, menjadi saksi karena Allah walaupun terhadap dirimu sendiri atau terhadap ibu bapak dan kaum kerabatmu. Jika dia (yang terdakwa) kaya ataupun miskin, maka Allah lebih tahu kemaslahatan (kebaikannya). Maka janganlah kamu mengikuti hawa nafsu karena ingin menyimpang dari kebenaran. Dan jika kamu memutar balikkan (kata-kata) atau enggan menjadi saksi, maka ketahuilah Allah Mahateliti terhadap segala apa yang kamu kerjakan.” (QS. An-Nisa : 135). ${ }^{21}$

Tatkala pembahasan Rancangan Kitab Undang-undang hukum Pidana dibahas, sebagian masyarakat Indonesia menginginkan berlakunya hukum Islam (hukum Fiqih), di antaranya sistem pemidanaan yang berlandaskan pada AlQurean dan sunnah Rasul bagi pelaku tindak pidana. Sebaliknya ada kelompok masyarakat yang tidak setuju dilaksanakannya pemberlakuan sistem pemidanaan berdasarkan hukum Islam yang dimasukkan dalam rancangan KUH Pidana dengan alasan hukum pidana Islam merupakan hubungan horisontal (yaitu pertanggungjawabannya kepada Allah) sedangkan hukum positif adalah hubungan vertikal (pertanggungjawabannya kepada negara) sering di istilahkan adanya pemisahan antara negara dan agama, di Indonesia terdiri dari berbagai agama dan kepercayaan, suku, ras, dan golongan. Hukum pidana Islam oleh sebagian orang sering dikatakan tidak manusiawi, kejam, melanggar hak asasi dan tidak relevan dengan perkembangan zaman. Akibatnya, ketika lahir keinginan untuk menetapkan

\footnotetext{
${ }^{21}$ Ibid. hlm 8
} 
syariah Islam terjadilah perdebatan yang panjang tentang hal itu.

Dari yang di sampaikan di atas telah tampak sebenarnya penegak hukum di perintahkan untuk dapat menegakan keadilan Berdaarkan Ketuhanan Yang Maha Esa, tetapi kebanyakan keadilan yang kita tegakkan tidak berlandaskan yang telah di perintahkan oleh aturan tersebut. Sebab saat ini peradilan kita telah banyak yang menggerogoti mulai dari tahap awal sampai tahap akhir Sistim Peradilan. Kalau saja keadilan itu di tegakkan sebagaimana mestinya maka akan tercipta suatu aturan yang relevan di masyarakat, tetapi masih saja melenceng dari ketentuan ayang ada.

Menurut Barda Nawawi Arif ada dua masalah sentral dalam kebijakan kriminal dengan menggunakan sarana penal (hukum pidana) ialah masalah penentuan;

1. perbuatan apa yang seharusnya dijadikan tidandak pidana; dan

2. sanksi apa yang sebainya digunakan atau dekenakan kepada si pelanggar. ${ }^{22}$

Pertanyaan diatas sangat simpel tapi pembahannya sangatlah rumuit apa lagi mencari solusinya. Maka negara kita memerlukan suatu pembaruhan yang mesti siqnifikan sehingga dapat mencegah

\footnotetext{
${ }^{22}$ Ibid hlm. 30.
}

serta memberantas kejahatan tersebut di kalangan masyarakat kita.

Penganalisisan terhadap dua masalah sentral ini tidak dapat dilepaskan dari konsepi integral antara kebijakan kriminal dengan kebijakan sosial atau kebijakan pembangunan nasional. Ini berarti pemecahan masalah-masalah di atas harus pula dirahkan untuk mencapai tujuan-tujuan tertentu dari kebijakan sasial-politik yang telah ditetapkan. Dengan demikian, kebijakan hukum pidana, termasuk pula kebijakan dalam menangani dua masalah sentral diatas, harus pula dilakukan dengan pendekatan yang berorientasi pada kebijakan (policy oriented approch). Sudah barang tentu pendekatan kebijakan integral ini tidak hanya dalam bidang hukum pidana, tetapi juga pada pembangunan hukum pada umumnya. Pendekatan demikian terlihat pula misalnya, pada tulisan Satjipto Raharjo yang berjudul "Pembangunan Hukum yang Dirahkan Kepada Tujuan Nasional." Dikemudian oelh Satjipto Rahrjo bahwa tidak dijumpai perbedaan antara fungsi hukum sebelum dan sesudah kemerdekaan. Perbedaannya terletak pada keputusan pokitik yang diambil dalam kedua masa tersebut dan pengimplementasiannya ke dalam sistem hukum masing-masing. Apabila keputusan politik yang di ambil setelah kemerdekaan 17 Agustus 1945 adalah mengutamakan 
kemakmuran rakyat yang sebesarbesarnya, maka keputusan demikian hanya dirumuskan dalam kaidah-kaidah hukum dan sturktur hukumnya pun harus menyediakan kemungkinan untuk melakukan hal itu. ${ }^{23}$

Dalam hal pembentukan suatu kebijakan yang akan diberlakukan di dalam masyarakat maka tetap mengaju kepada kemanfaatan di dalam masyarakat, agar terciptanya suatu aturan yang mampu mendorong terbentuknya suatu paradigma baik untuk menjalankan kebijakan yang telah di buat. Kebijakan hukum pidana yang seharusnya baik psti akan melahirkan suatu akibat yang baik pula di di dalam masyarakat.

Hukuman, pidana dan pemidanaan merupakan bagian yang tidak terpisahkan dari hukuman pidana, karena pada intinya, sebagaimana menurut Moeljatno ${ }^{24}$ hukum pidana adalah hukum yang mengatur untuk:
a. Menentukan perbuatan-perbuatan mana yang tidak boleh dilakukan, yang dilarang, dengan disertai ancaman atau saksi berupa pidana tertentu bagi barang siapa melanggar larangan tersebut;
b. Menentukan kapan dan dalam hal apa kepada mereka yang telah melanggar

\footnotetext{
${ }^{23}$ Ibid hlm. 31.

${ }^{24}$ Moeljatno, 1996, Kitab Undang-Undang Hukum Pidana, Jakarta: Bumi Aksara, hlm 5-6.
}

larangan-larangan itu dapat dikenakan atau dijatuhi pidana sebagimana yang telah dicantumkan;

c. Menentukan dengan cara bagaimana pegenaan pidana itu dapat dilaksanakan apabila ada orang yang disangka telah melanggar larangan tersebut.

Menurut H.L.A. Hart Pidana merupakan salah satu unsur yang esensial bdi dalam hukum pidana. Pidana itu harus: $:^{25}$

a. Mengandung penderitaan atau konsenkuensi lain yang tidak menyenangkan.

b. Dikenakan pada seseorang yang benar-benar atau disangka benar dalam melakukan tindak pidana.

c. Dikenakan berhubung suatu tindak pidana yang melanggar ketentuan hukum.

d. Dilakukan dengan sengaja oleh orang selain pelaku tindak pidana.

e. Dijatuhkan dan dilaksanakan oleh penguasa sesuai dengan ketentuan suatu sistem hukum yang dilanggar oleh tindak pidana tersebut.

Dan menurut Roeslan saleh arti pidana adalah reaksi atas delik, dan ini terwujud suatu nestapa yang dengan sengaja ditimpahkan Negara pada

25 Dalan Buku Djarijah, Nunung Marlina. 2001. Budidaya Jamur Tiram, Pembibitan, Pemeliharaan, dan Pengendalian Hama Pemyakit, Yogyakarta: Kanisius, hlm 21 
pembuat delik itu. Sedangkan Van Hamel $^{26}$, mengatakan bahwa Pidana atau straf menurut hukum positif dewasa ini adalah: suatu penderitaan yang bersifat khusus, yang telah dijatuhkan oleh kekuasaan yang berwenang untuk menjatuhkan pidana atas nama negara sebagai penanggungjawab dan ketertiban hukum umum bagi seorang pelanggar, yakni semata-mata karena orang tersebut telah melanggar suatu peraturan yang harus diterapkan oleh negara.

Disisi lain salah satu norma atau kaidah yang berlaku di masyarakat adalah hukum Islam. Abu Ishaq al shatibi ${ }^{27}$ mengatakan bahwa Tujuan hukum Islam dari segi manusia yang menjadi pelaku dan pelaksanaan hukum Islam, yakni :

1. Untuk memenuhi keperluan hidup manusia yang bersifat primer, sekunder dan tertier yang dalam kepustakaan hukum Islam masingmasing disebut dengan istilah daruriyyat, hajjiyat dan tahsiniyyat.

2. Untuk mentaati dan dilaksanakan oleh manusia dalam kehidupan seharihari

3. Supaya dapat ditaati dan dilaksanakan dengan baik dan benar.

${ }^{26} \mathrm{Ibid}$.

27 Mardani, 2010, Hukum Islam : pengantar ilmu hukum Islam di Indonesia, Yogyakarta: Pustaka Pelajar, hlm 20
Kebijakan negara menjadikan syariah sebagai hukum negara semakin intens dilakukan awal abad XX, ketika terjadi proses pembentukan negara-negara di dunia Islam, bersamaan dengan berakhirnya dominasi kolonialisme Barat di negara-negara Muslim seperti Turki, Mesir, Sudan, Maroko, Pakistan, Malaysia, dan Aljazair. Negara-negara Muslim ini mengalami kesulitan mengembangkan hubungan yang memungkinkan (viable) antara syariah dan negara. Perdebatan terhadap syariah bukan hanya di negara mayoritas Muslim, tetapi merambah ke negaranegara sekuler.5 Terlebih lagi, migrasi masyarakat Muslim telah membawa perdebatan ini ke Benua Eropa, Amerika Utara, dan Amerika Selatan. ${ }^{28}$

Walaupun demikian, kita harus memandang ikhtilaf ini seiring dengan dua prinsip islam lainnya, yakni tawhid, atau kepercayaan akan Keesaan Tuhan dan pengaruhnya yang demikian jauh dalam pemikiran hukum islam. Tawhid adalah unsur pertama keimanan umat Muslima dan merupakan teman besar dalam Al-Qur'an. Hanya ada satu tuhan. Demikian pula, hanya ada satu islma, satu kitab suci, satu ummah (komunitas) dan

\footnotetext{
${ }^{28}$ Muhammad Khalid Mas'ud, 2003, "Pencarian Landasan Normatif Syariah Para Ahli Hukum Islam" dalam Dinamika Kontemporer Dalam Masyarakat Islam, dihimpun oleh Dick van der Meij, diterjemahkan oleh Soemardi, Jakarta: INIS, hlm. 3.
} 
satu Syariah. Wujud simbolis kesatuan iman ini juga terlihat dari bagaiman semua umat Muslim shalat menghadap ke arah Ka'bah. Kesatuan dalam esensi keimanan tidak terbuka pada perbedaan di tingkan apa pun. Al-Qur'an (QS. Al-Anbiya : 92) menyatakan umat Muslim sebagai satu bangsa-ummatan wahidatan yang sekaligus menjadi saksi dan penjaga kesatuannya. Bisa saja ada banyak mahzab berbedam, masing-masing dengan interprestasi Syariah yang sama-sama sah, namun pluralitas pada tingkat ini tidak mengubah kenyataan bahwa hanya ada satu syariah yang termanifestasi dalam perintah tesktual yang jelas dalam AlQur'an dan Sunnah. Masing-masing mahzab menafsirkan syariah sesuai dengan kebutuhan dan realita zamanya. Tak satupun mengklaim dirinya sebagai syariah itu sendir, melainkan penafsiran atas Sayriah yang sama, yang dimiliki oleh semua. Fiqih terutama membahas mengenai prktik perilaku dan ia bukan esensi dari iman itu sendiri. Syariah lebih luas dari fiqih karena ia mencakup tidak hanaya satu aturan-aturan hukum praktis namun juga teologi dogmatis dan ajranajaran moral. Oleh karenanya fiqih juga diturunkan dari Syariah; ia tidak sepenuhnya orisinal dan tidak juga seluruhnya didasarkan pada opini pribadi. $^{29}$

Hal ini berbeda dengan konsep hukum di luar Islam yang hanya ditujukan untuk mengatur kehidupan manusia selaku anggota masyarakat. Dalam pandangan hukum di luar hukum Islam, bahwa hukum itu sebagai hasil proses kehidupan manusia dalam bermasyarakat, sebagaimana yang diungkapkan oleh Cicero bahwa "Ubi Sociates Ibilius" (dimana ada Masyarakat di sana ada hukum). Dalam tata aturan hukum di luar Islam aturan yang berkaitan dengan kehidupan pribadi tidak dinamakan hukum, la dinamakan norma, moral, budi pekerti atau etika. ${ }^{30}$

Sebenarnya menurut pandangan saya masalah ini tidak harus menjadi perdebatan diantara kalangan ummat Islam, karena nash-nash Al Qur'an dan As Sunnah mengenai hudud maupun qishash adalah jelas (qath'i) sifatnya. Karena itu, tidak bisa dihilangkan, dirubah atau dihapuskan. Adapun masalah akan diterapkan atau tidak, dapat dilihat pada penerapannya dalam kasus in concrito. Artinya hudud maupun qishash hanya dapat diterapkan apabila memenuhi syarat-syarat perbuatan pidana yang

\footnotetext{
${ }^{29}$ Mohammad Hasim Kamali, 2013, Membumikan Syariah Pergaulatan Mengaktualkan Islam, Bandung: Mizan, hlm. 130.

${ }^{30}$ Suparman Usman, 2001, Hukum Islam, Asas-asas dan Pengantar Studi Hukum dalam Tata Hukum Indonesia, Jakarta: Gaya Media Pratama, hlm 23.
} 
sedemikian rupa kwaliatsnya baik dari sisi beratnya tindak pidana yang dilakukan, dari sisi causanya, maupun pengaruhnya pada bidang sosial dan publik. Bukankah Umar ra pernah tidak menghukum pencuri dengan potong tangan karena kondisi sosial dan keadaan sipencuri yang sedemikian sulitnya. Dengan demikian kita tidak melakukan perubahan atas hukum yang telah ditentukan dengan pasti oleh Allah ini.

Suatu hukum dibuat oleh para pihak yang berwenang tidak mungkin begitu saja dibuat tanpa ada makna di balik pembuatannya. Setiap hukum yang dibentuk mempnyai tujuan yang hendak dicapai, begitu juga yang lainnya. Adapun tujuan hukum dibentuk suatu hukum menurut para ahli yang yaitu sebagai berikut:

1. Van Apeldoorn; berpendapat bahwa tujuan hukum itu untuk mengatur tata tertib masyarakat secara damai dan adil;

2. Bentham; berpendapat bahwa hukum bertujuan menjamin adanya bahagia sebanyak-banyaknya pada orang sebanyak-banyaknya;

3. Van Kan; menagatkan bahwa hukum bertujuan menjaga kepentingan tiaptiap menausia supaya kepentingan itu tidak dapat di ganggu;

4. Syaikh Muhammad Al-Khudhariy; mendefinisikan hukum adalah kitab
Allah yang berhubungan dengan perbuatan manusia dewasa, baik yang berupa perintah atau menjadikan sesuatu sebagai sebab, syarat dan penghalang

5. Abdul Wahhab Khallaf; memberi defenisi hukum adalah doktrin syari' yang bersangkutan dengan perbuatan orang-orang mukallaf secara perintah atau perintah meilih atau berupa ketetapan. $^{31}$

Sebenarnya tujuan hukum itu telah memberikan kita sinyal bahwasanya sebaik-baik hukum itu yang bermanfaat untuk masyarakat dan dapat terjalankan serta memiliki suatu efek yang baik di dalam masyarakat banyak. Kalau kita melihat hukum pidana kita saat ini (KUHP) yang diberlakukan untuk menyelesaikan suatu permasalahan yang terdapat di dalam masyarakat tidak seimbang dan masih adanya stigma yang kurang setelah pemberlakukan aturan pidana tersebut. Perlu kita mengkajinya mulai dari sudut pandangan masyarakat yang menjadi korban dan sudut pandang yang menjadi pelaku (baik keluarganya maupun pelaku sendiri) apakah sudah memenuhi kemanfaatan yang menyeluruh atau belum. Dalam hal ini kalau kita hanya menggunakan suatu aturang yang

\footnotetext{
${ }^{31}$ Sholeh So'an, 2004, Moral Penegakan Hukum di Indonesia Dalam Pandangan Islam, Bandung: Agung
} Ilmu, hlm 48-49. 
telah ada saat ini (KUHP) masih belum cukup mengkoordinir keadaan setelah diberlalukannya atauran pidananya.

Hukum pidana Islam (fiqh jinayah) merupakan syariat Allah SWT yang mengatur ketentuan hukum mengenai tindak pidana atau perbuatan kriminal yang dilakukan oleh orang-orang mukallaf (orang yang dapat dibebani kewajiban), sebagai hasil dari pemahaman atas dalildalil hukum yang terperinci dari Al Qur'an dan Hadist. Hukum pidana Islam pada hakikatnya mengandung kemaslahatan bagi kehidupan manusia baik di dunia maupun di akhirat. Syariat Islam dimaksud, secara materil mengandung kewajibanasasi bagi setiap manusia untuk melaksanakannya. Konsep kewajiban asasi syariat menempatkan Allah SWT sebagai pemegang segala hak. ${ }^{32}$

Cakupan melanggar hukum di dalam hukum positif hanya terbatas kepada perbuatan yang salah atau melawan hukum terhadap bidang-bidang hukum tertentu seperti bidang hukum pidana, perdata, tata usaha Negara, hukum pertanahan dan sebagainya. Sedangkan di dalam hukum Islam, terhadap hal-hal yang dianggap salah atau melanggar hukum adalah sesuatu yang melanggar ketentuan-

\footnotetext{
${ }^{32}$ Dede Rosyada, 1992, Hukum Islam dan Pranata Sosial, Lembaga Studi Islam dan Kemasyarakatan, Jakarta, hlm 86., sebagaimana dikutip oleh Zainuddin Ali, 2007, Hukum Pidana Islam, Cet. 1, Jakarta: Sinar Grafika, hlm 1.
}

ketentuan hukum syariat, yang dasar hukumnya dapat ditemui di dalam Al Qur'an, Hadist, maupun Ijtihad para ulama. Ketentuan-ketentuan syariat ini tidak hanya berkaitan dengan hubungan muamalah saja, tetapi juga menyangkut ibadah, yang pada dasarnya pelanggaran terhadap ketentuan tersebut semuanya akan mendapatkan hukuman, meskipun hukuman terhadap perbuatan tersebut ada yang diterima di dunia maupun ada hukuman yang akan diberikan di akhirat kelak. $^{33}$

Konsep jinayah atau dalam istilah Indonesia disebut pidana, membicarakan tentang masalah larangan, karena setiap perbuatan yang dilakukan berkaitan dengan larangan selalu terangkum dalam konsep jinayah yang merupakan perbuatan tersebut dilarang oleh syara'. Lahirnya larangan karena perbuatan tersebut mengancam kehidupan sosial masyarakat atau sendi-sendi kehidupan masyarakat.

Kata jinayat atau disebut dengan Fiqh Jinayah merupakan satu bagian dari bahasan fiqh (Fikih), kalau pemahaman fiqh itu adalah ketentuan yang berdasarkan wahyu Allah dan bersifat amaliah (operasional) yang mangatur tentang kehidupan manusia dalam sistem hubungannya dengan Allah dan manusia,

\footnotetext{
${ }^{33}$ Lysa Angrayni, Hukum Pidana Dalam Perspektif Islam dan Perbandingannya Dengan Hukum Pidana di Indonesia, Hukum Islam, Vol. XV No. 1 Juni 2015.
} 
maka fiqh jinayah secara khusus mengatur tentang pencegahan tindak kejahatan yang dilakukan oleh manusia dan akan diberikan sanksi hukuman sesuai dengan tingkat kejahatan, karenanya tujuan dari ketentuan itu tidak lain diciptakan Allah adalah untuk mendatangkan kemaslahatan ummat. Hal ini dipertegas oleh hadits Nabi SAW, yang mengatakan "tidak boleh terjadi kerusakan terhadap manusia dan tidak boleh manusia melakukan perusakan terhadap orang lain". Segala bentuk tindakan pengrusakan terhadap orang ataupun makhluk lainnya di larang oleh agama dan tindakan tersebut merupakan kejahatan atau disebut dengan jinayah atau istilah yang lebih tepat untuk itu disebut dengan jarimah. ${ }^{34}$

Ada beberapa bentuk pidana atau jinayah dengan istilah jarimah yang disebutkan dalam pidana Islam, di lihat dari segi mengerjakannya, yaitu :

1. Dengan cara berbuat atau melakukan tindak pidana, disebut dengan jarimah ijabiyah/delict commisionis

2. Dengan cara tidak melakukan/melaksanakan hal yang diperintahkan, disebut dengan jarimah salabiyah/delict ommisonis

3. Jarimah ijabiyah taqa'u bithariqalsalab/delict commisionis per ommisionem commisa. Jenis jarimah

\footnotetext{
${ }^{34}$ Amir Syarifuddin, 2003, Garis-garis Besar Fiqh, edisi pertama, Prenada Media, Jakarta, hlm 253
}

yang ketiga ini adalah menahan seseorang tahanan dengan tidak memberi makan dan tidak memberi minum sehingga tawanan tersebut meninggal. Hal inilah sebagaimana dicontohkan oleh mazhab Maliki, Syafi'i dan Hanbali. ${ }^{35}$

Terlepas dari perbedaan pandangan mengenai tentang bentuk atau istilah yang tepat terhadap perbuatan itu disebut jinayat atau jarimah, dalam hal ini jarimah dibagi ke dalam tiga golongan :

1. Golongan jarimah hudud, yang terdiri dari perzinahan, menuduh orang lain berzina, meminum minuman khamar (memabukkan), merampok, merusak, membuat onar, murtad dan memberontak.

2. Golongan jarimah qishash atau diyat, yang terdiri atas pembunuhan sengaja, pembunuhan mirip sengaja dan pembunuhan tidak sengaja

3. Golongan jarimah ta'zir, yaitu larangan/perintah tentang sesuatu hal yang tidak dirumuskan secara pasti, termasuk sanksinya dan pelaksanaan hukumannya diserahkan kepada pihak penguasa. $^{36}$

\footnotetext{
${ }^{35}$ Teguh Prasetyo dan Abdul Halim Barkatullah, 2005, Politik Hukum Pidana, kajian kebijakan kriminalisasi dan dekriminalisasi, Cet. I, Yogyakarta: Pustaka Pelajar, hlm. 130

${ }^{36}$ Ali Yafie, Ahmad Sukarja, Muhammad Amin Suma, dkk, 2008, Ensiklopedi Hukum Pidana Islam, Edisi Indonesia, Jilid I, Jakarta: Kharisma Ilmu, hlm. 88
} 
Suatu perbandingan bila di lihat dalam Kitab Undang-Undang Pidana Mesir, terdapat tiga macam penggolongan tindak pidana yang didasarkan kepada berat ringannya hukuman, yaitu;

(1) Jinayah (kejahatan); suatu tindak pidana yang diancamkan hukuman mati, hukuman kerja berat seumur hidup, hukuman kerja berat sementara dan hukuman penjara (Pasal 10),

(2) Janhah (kejahatan ringan); suatu tindak pidana yang dijatuhi hukuman kurungan lebih dari satu minggu atau hukuman denda lebih dari 100 qirasy (Pasal 11), dan

(3) Mukhalafa (pelanggaran); suatu tindak pidana yang dijatuhi hukuman tidak lebih dari satu minggu atau hukuman denda ynag jumlahnya tidak lebih dari 100 qirasy (Pasal 12). ${ }^{37}$

Hukuman dalam hukum pidana Islam dalam Bukunya Drs. H. Ahmad Wardi Muslich adalah sebagai berikut $:^{38}$

1. Hukuman-hukuman untuk jarimah Hudud

a. Hukuman jarimah Zina. Syari'at Islam telah menetapkan tiga jenis hukuman untuk jarimah Zina yaitu dera' jilid, rajam.

b. Hukuman jarimah Qadzaf. Hukuman untuk jarimah Qadzaf

${ }^{37}$ Ibid.

${ }^{38}$ Ahmad Wardi Muslich, 2004. Pengantar dan Asas Hukum Pidana Islam Fiqih Jinayah, Jakarta: Sinar Grafika, hlm. 145-163 ada dua yaitu hukum pokok yaitu jilid (dera), hukuman tambahan yaitu pencabutan hak sebagai saksi.

c. Hukuman minum-minuman keras. Hukuman untuk jarimah minumminuman keras adalah delapan puluh kali jilid (dera).

d. Hukuman jarimah pencurian. Jarimah Pencurian diancam dengan potong tangan

e. Hukuman jarimah perampokan. Syari'at Islam menetapkan empat macam hukuman untuk tindak pidana perampokan (hirabah) yaitu:

a) Hukuman mati: kepada perampok apabila mereka melakukan pembunuhan.

b) Hukuman mati dan salib; Dijatuhkan apabila perampok melakukan pembunuhan dan merampas harta benda.

c) Hukuman potong tangan dan kaki; Dijatuhkan apabila perampok hanya mengambil harta tanpa melakukan pembunuhan, dalam hal ini anggota badan yang dipotong adalah tangan kanan dan kaki kiri pelaku.

d) Hukuman pengasingan;

Hukuman pengasingan dijatuhkan apabila perampok 
hanya menakut-nakuti orang yang lewat dijalan, tetapi tidak mengambil harta benda dan tidak pula membunuh

e) Hukuman jarimah Riddah

Hukuman riddah diancam dengan dua jenis hukuman:

i. Hukuman pokok yaitu hukuman mati

ii. Hukuman tambahan yaitu penyitaan harta benda

f. Hukuman jarimah

Pembrontakan

Hukuman untuk jarimah pembrontakan adalah

hukuman mati

2. Hukuman untuk jarimah Qishas-Diat

a. Pembunuhan sengaja

b. Pembunuhan menyerupai sengaja

c. Pembunuhan karena kesalahan (tidak sengaja)

d. Penganiayaan sengaja

e. Penganiayaan karena kesalahan (tidak sengaja)

3. Hukuman-hukuman yang diancam dengan jarimah

a. Qishas

b. Diat

c. Kifarat (jenis hukumannya adalah membebaskan seorang hamba yang mukmin, apabila tidak ada diganti dengan puasa dua bulan berturut-turut) Hilangnya hak

waris dan hak wasiat

4. Hukuman jarimah Ta'zir

Hukuman ta'zir jumlahnya cukup banyak, mulai dari hukuman yang paling ringan sampai yang paling berat. Dalam penyelesaian perkara yang termasuk jarimah ta'zir, hakim diberi wewenang untuk memilih diantara kedua hukuman tersebut, mana yang paling sesuai dengan jarimah yang dilakukan oleh pelaku, jenis-jenis hukuman ta'zir ini adalah hukuman mati, hukuman jilid, hukuman kawalan, hukuman pengasingan, hukuman salib, hukuman pengucilan, hukuman ancaman, teguran, peringatan, hukuman denda. Disamping itu juga ada hukuman-hukuman lain yang sifatnya spesifik dan tidak bisa diterapkan pada setiap jarimah ta'zir, diantara hukuman tersebut adalah pemecatan dari jabatan atau pekerjaan, pencabutan hak-hak tertentu, perampasan alat-alat yang digunakan untuk jarimah, penayangan gambar penjahat dimuka umum atau televise dan lain-lain. ${ }^{39}$

Penjelasaan di atas adalah beberapa ancaman pidana yang berlaku di dalam islam kalau di bandingkan dengan hukum pidana indonesia (hukum positif/KUHP) sangat jauh berbeda dalam hal pemberian sanksi pidana kepada para pelaku tindak pidana. Dan telah tampaklah perbedaan yang sangat signifikan dalam hal penjatuhan pidana yang

\footnotetext{
${ }^{39}$ Ibid.
} 
berdasarkan KUHP dan Hukum Pidana Islam.

Di dalam hukum pidana yang berasal dari KUHP hampir semua tindak pidana di jatuhi suatu ancaman pidana kurungan (menghilangkan kebebasan seseorang). Kalau kita berkaca dari hukum positif yang ada saat ini (KUHP) menurut tulisan ini bahwa hukuman yang diberikan kepada seorang pelaku kejahatan kalau hanya merenggut kebebasan saja dirasa masing kurang adail dan belum cukup mengobati rasa sakit/kehilangan yang dirasakan oleh korban ataupun pihak keluarga korban.

Kalaulah saja kita menelusuri lebih jauh dari akibat dari kejahatan yang dilakukan oleh si pelaku dengan adanya hukuman yang dijatuhkan oleh negara (penegak hukum), para pihak korban ataupun keluarga banyak yang tidak merasakan keadilan tersebut contohnya saja kalau kita melihat kasus pemerkosaan yang berujung kepada kematian sudah sangat banyak sekali, tetapi hukum pidana kita hanya memberikan ancaman kepada si pelaku kebanyakan adalah pidana perampasan kebebasan si pelaku saja. Contoh saja kasus yang masih segar di ingatan, seorang anak yang masih duduk di kursi SMP di perkosa di sebuah hutan (jalan mau kerumah korban) oleh belasan orang sehingga si Anak tersebut sampai meninggal dunia. Tapi apa yang dilakukan oleh pihak negara (pemrintah/penegak hukum) hanya menjatuhkan hukuman penjaara 10 tahun penjara.

Kalau kita menimbang dengan tujuaan hukum yaitu keadilan, kemanfaatan dan kepastian hukum ini belum cukup untuk membalas kesakitan yang dirasakan oleh keluarga korban karena korban tidak akan pernah kembali lagi karena sudah meninggal dunia, sedangkan pelaku masih bisa bebas hidup setelah menjalani hukamanya selama 10 tahun. Apakah ini adalah sebuah keadilan atau tidak? Tentu saja ini tidak adil bagi keluarga korba, seharusnya kalau ada pembunuhan maka dibalas dengan nyawa.

Di dalam hukum islam mengatur segala hukuman memang berdasarkan kedalam tingkatan kejahatan yang terjadi, tetapi dalam islam ini juga mengenal yang namanya sutu tindakan untuk menghapus dosa dan mempertanggungjawabkan perbuatannya. Karena di dalam hukum pidana islam setelah melaksanakan seluruh proses peradilan yang dijatuhkan kepada pelaku, maka pelaku akan merasakan satu nestapa yang sesungguhnya sebab dia akan mempertanggungjawabkan perbuatannya dengan melalui segala hukuman yang telah ditetapkan. Kalau dia melakukan perbuatan membunuh apabila terbukti maka akan di bunuh sesuai dengan perbuatannya, kalua mencuri terbukti maka akan dilakukan hukuman potong tangan (ini juga melihat dari kondisi social yang melakukan) dan seterusnya yang telah dijelaskan diatas. 
Maka setiap kejahatan yang dilakukan oleh pelaku kejaahatan maka si pelaku akan mempertangggungjawabkan segala perbuatannya, sehingga ketika dilakukan hukuman yang dianut oleh hukum islam maka setiap pembalasan serta rasa keadilan yang dicita-citakan akan tercipta sendirinya serta ketika hukum islam ini di anut oleh negara Indonesia (dalam pembaharuan KUHP) maka efek jera juga akan biasa dirasakan oleh si pembuat kejahatan dan masyarakat juga yang melihat hukuman yang demikian akan merasa takut akan melakukan kejahatan yang telah dilakukan oleh orang yang telah dihukum.

Kalau kita berbicara tentang hukum islam melanggar Hak Asasi Manusia (HAM), kalau kita mengaca kepada hukum negara kita mana yang tidak melanggar Hak Asasi seseorang, kalau seseorang melakukan kejahatan contohnya saja melakukan pembunuhan ketika terbukti di persidangan maka akan di penjara. Penjara bukanya suatu hal yang merenggut/merampas kemerdekaan seseorang. Jadi ketika kita menerapkan hukum islam bukan perkara melanggar HAM seseorang tapi kita mau melakukan perubahan dalam hal kebijakan hukum pidana atau tidak, masalahnya cuma ada disana negara kita belum mau beranjak kepada hal yang lebih konkrit dan memberikan suatu keadilan dan keteraman di dalam negara kita.
Maka perlu sebenarnya negara (melalui lembaga legislatif) melakukan restrukturisasi KUHP kepda hukum yang lebih baik agar terciptanya suatu hukum yang baik di dalam negara terutama meberantas kejahatan yang sudah sangat meresahkan dan bahkan sudah membuat masyarakat Indonesia dibuat lengah dan dibiarkan saja begitu saja, sedangkan di dalam pembukaan UndangUndang Dasar 1945 Pasal 1 ayat 3 telah tegas dikatakan bahwa anegara Indonesia adalah negara hukum. Maka laksanakanlah hukum itu sebagai mana mestnya agar menjadi pelindung di dalam masayarakat sehingga terciptalah masyarakat yang adil dan sejahtera lagi tentram.

\section{Penutup}

\section{Kesimpulan}

Penegakan Hukum dalam proses hukum pidana yang dilakukan di Indonesia (Hukum Positif) saat ini ialah menggunakan yang Kitap Undang-Undang Hukum Pidana (KUHP) yang notabena merupakan hasil pemikiran dari Negara Penjajah Indonesia yaitu Negara Belanda. Hukum pidana yang dibawa belanda sampai saat ini masih eksis di Indonesia disebabkan karena tidak adanya perubahan suatu Perundang-Undangan hukum pidana secara menyeluruh, walaupun Undang-Undang Indik tentang hukum pidana ini sudah dilakukan perubahan secara parsial saja, tetapi peraturan perundang-undangan yang ruhnya sebenarnya masih banyak yang 
tidak sesuai dengan ruh dan jiwa bangsa negara indonesia. Bahwa hukum pidana yang terdapat di dalam KUHP saat ini yang digunakan untuk memidanakan seseorang yang melakukan tindak pidana ialah Pasal 10 KUHP sebagai berikut:

a. Pidana Pokok:

1. Pidana Mati

2. Pidana penjara

3. Kurungan

4. Denda

b. Pidana Tambahan

1.Pencabutan hak-hak tertentu

2.Perampasan barang-barang tertentu

3.Pengumuman putusan hakim.

Bahwa melihat hukum yang diterapkan di Indonesia merupakan suatu hukuman atau pidana yang hanya bersifat kebanyakan melindungi hak-hak si pelaku tindak pidana, tetapi masih adanya suatu paradigma yang masih tidak adanya suatu keadilan yang merata antara si pelaku dan korban dalam suatu tindak pidana.

Berbeda dengan pemberlakuan hukum islam dalam penegakan hukum yaitu dengan hukuman sebagai berikut

a. Hukuman-hukuman untuk jarimah Hudud

b. Hukuman untuk jarimah Qishas-Diat

c. Hukuman-hukuman yang diancam dengan jarimah

d. Hukuman jarimah Ta'zir

Bahwa melalui penegakan hukum islam digunakan sebuah pidana yang mengenal adanya sistem penghapus pidana dan penghapusan dosa sehingga hukum pidana islam lebih kepada bagaimana sipelaku tindak pidana mendapatkan suatu pemaafan serta pengampunan dosa dari perbuatan yang dilakukan oleh si pelaku tindak pidana. Sehingga dalam hukum pidana islam mengenal yang namanya suatu hukuman yang bersifat suatu keadilan yang merata antara pelaku dan si korban yang disebabkan oleh perbuatan si pelaku. Sehingga Hukum pidana islam lebih memberikan suatu proses hukuman yang lebih baik sehingga tidak akan munculnya suatu stigma yang mengatakan suatu kejahatan bisa bebas begitu saja setelah menjalani hukuman tetapi lebih mengena dan lebih memberikan efek jera yang lebih baik, baik itu kepada si pelaku kejahatan maupun kepada masyarakat. Pemberlakuan hukum pidana islam sepertinya mampu menjawab semua persoalan yang di alami oleh negara ini dan lebih memliki suatu tingkat keadilan dan kemanfaatn serta lebih adanya suatu kepastian hukum sebab di dalam hukum islam terlah terdapat suatu hukuman yang langsung meberikan suatu penghapusan dosa dan pertanggungungjawaban pidana sedangkan di dalam hukum positif (KUHP) hanya memberikan pertanggungjawaban yang tidak merata antara kejahatan dan hukuman yang diberikan. 


\section{Saran}

1. Bahwa perlu adanya suatu pembaharuan hukum pidana positif ke arah yang lebih baik agar menciptakan suatu tujuan hukum sebagaimana yang dicita-citakan

2. Perumusan KUHP yang baru seharusnya mengadopsi sebagian hukum pidana islam yang menyangkut suatu adanya menciptakan tujuan hukum yan dicitacitakan.

3. Penting rasanya melakukan suatu perubahan terhadap langkah-langkah dalam Sistem Peradilan Pidana seperti pada tingkat kepolisian, jaksa pnuntut umum, pengadilan dan lembaga permasyarakatan yang lebih baik.

\section{Daftar Pustaka}

Agustinus Pohan, Topo Santoso, dan Martin Moerings, 2012, Hukum pidana dalam perspektif, Denpasar: Pustaka Larasan, Jurnal Hukum yang di Terjemahkan.

Ali Yafie, Ahmad Sukarja, Muhammad Amin Suma, dkk, 2008, Ensiklopedi Hukum Pidana Islam, Edisi Indonesia, Jilid I, Jakarta: Kharisma Ilmu.

Andi Hamzah, 1994, Azas Azas Hukum Pidana, cet 2, Jakarta: J Rineka Cipta.

Angrayni, Lysa, Hukum Pidana Dalam Perspektif Islam dan Perbandingannya Dengan Hukum Pidana di Indonesia, Hukum Islam, Vol. XV No. 1 Juni 2015.

Arief, Barda Nawawi, 2006, Masalah Openegakan hukum dan Kebijakan hukum Pidana dalam Penanggulangan, Semarang: Kejahatan, Kencana, , hlm. 5.
Efendi, Erdianto, 2011, Hukum Pidana Indonesi Suatu Pengantar, PekanbaruBandung: Refika Aditama.

Kamali, Mohammad Hasim, 2013, Membumikan Syariah Pergaulatan Mengaktualkan Islam, Bandung: Mizan.

Mardani, 2010, Hukum Islam : pengantar ilmu hukum Islam di Indonesia, Yogyakarta: Pustaka Pelajar.

Marlina, Nunung, 2001. Budidaya Jamur Tiram, Pembibitan, Pemeliharaan, dan Pengendalian Hama Pemyakit, Yogyakarta: Kanisius.

Mas'ud, Muhammad Khalid, 2003, "Pencarian Landasan Normatif Syariah Para Ahli Hukum Islam" dalam Dinamika Kontemporer Dalam Masyarakat Islam, dihimpun oleh Dick van der Meij, diterjemahkan oleh Soemardi, Jakarta: INIS.

Moeljatno, 1996, Kitab Undang-Undang Hukum Pidana, Jakarta: Bumi Aksara.

Muslich, Ahmad Wardi, 2004. Pengantar dan Asas Hukum Pidana Islam Fiqih Jinayah, Jakarta: Sinar Grafika.

Prasetyo, Teguh, 2010, Hukum Pidana Edisi Revisi, Yogyakarta: Rajawali Pers.

Raharjo, Satjipto, 1983, Masalah Penegakan Hukum, Bandung: Sinar baru.

Raharjo, Satjipto, 2002 Sosiologi Hukum, Perkembangan, Metode dan Pilihan Masalah, Surakarta: Muhammadiyah University Press.

Rosyada, Dede, 1992, Hukum Islam dan Pranata Sosial, Lembaga Studi Islam dan Kemasyarakatan, Jakarta, hlm 86., sebagaimana dikutip oleh Zainuddin 
Ali, 2007, Hukum Pidana Islam, Cet. 1, Jakarta: Sinar Grafika.

So'an, Sholeh, 2004, Moral Penegakan Hukum di Indonesia Dalam Pandangan Islam, Bandung: Agung Ilmu.

Soekanto, Soerjono, 1999, Pokok Pokok Sosiologi Hukum, cet 9, Jakarta: Raja Grafindo Persada.

Syarifuddin, Amir, 2003, Garis-garis Besar Fiqh, edisi pertama, Jakarta: Prenada Media.
Teguh Prasetyo dan Abdul Halim Barkatullah, 2005, Politik Hukum Pidana, kajian kebijakan kriminalisasi dan dekriminalisasi, Cet. I, Yogyakarta: Pustaka Pelajar.

Usman, Suparman, 2001, Hukum Islam, Asas-asas dan Pengantar Studi Hukum dalam Tata Hukum Indonesia, Jakarta: Gaya Media Pratama. 